DOI: $10.2478 /$ ausp-2020-0022

\title{
Humour as a Postmodern Weapon in a Totalitarian Regime. Ioan Groşan's One Hundred Years at the Gates of the East
}

\author{
Zsuzsa TAPODI \\ Sapientia Hungarian University of Transylvania (Cluj-Napoca, Romania) \\ Department of Human Sciences \\ tapodizsuzsa@uni.sapientia.ro \\ Ingrid TOMONICSKA \\ Sapientia Hungarian University of Transylvania (Cluj-Napoca, Romania) \\ Department of Human Sciences \\ tomonicskaingrid@uni.sapientia.ro
}

\begin{abstract}
The paper aims to show that $O$ sută de ani de zile la Porțile Orientului [One Hundred Years at the Gates of the East], Ioan Groşan's historical picaresque postmodern novel, can be seen - due the presence of different techniques and devices of humour - as a weapon in and against a totalitarian system. In order to do so, our approach takes into account the problem of an East European totalitarian system, the East-West antipode, the condition of the author and his possible intention in a totalitarian system, the condition of the reader and his horizon of expectations in the same system, and the sources of humour used by the author. Humour as a weapon can have a lot of roles, for example, cracking, evading, or surmounting reality, and we want to show that Ioan Groşan succeeds in doing all that. In our paper, we grouped the humour-generating incongruences and contradictions into several categories: composition, frame (space and time, situations), identity (social status, names, physical appearance, ethnic and religious belonging), and language to underline the wide range of tools used by the author.
\end{abstract}

Keywords: Ioan Groşan, totalitarian system, Postmodernism, humour

\section{Introduction}

Evasion from an unbearable universe is an ancient practice. The causes and solutions are multiple, the reason behind it being the search for an alternative universe free of social and historical rules, which is able to offer an alternative. Virtuality, no matter whether it is (literary) fiction or a computer-simulated environment, can be 
regarded as the psyche's means of self-defence, a promise of a better life as well as a task in order to be accomplished or "a problem to solve".

The aim of this paper is to highlight that by means of his postmodern novel One Hundred Years at the Gates of the East ${ }^{1}$ Ioan Groşan - one of the "best-known 'fiction writers' of the eighties"2 (Cărtărescu 2010: 423) 3 - not only creates an alternative, hybrid, fictional literary world but also offers an alternative history, a stand-up history (Stan 2008: 5), humour used as a weapon against a totalitarian regime being one of his main devices.

Our approach is focused on three coordinates, the first one representing the social, historical, and literary context in which Ioan Groşan lived and worked, the second one is the author, the paper trying to identify the intentions, strategies, and devices of humour used by the writer, while the third one is the audience and their horizon of expectations.

\section{Context. Introduction to the social, historical, and theoretical background}

A detailed presentation of the crimes committed by the totalitarian regime has been elaborated by the Presidential Commission for the Study of the Communist Dictatorship in Romania headed by Vladimir Tismăneanu, which published a detailed report on this topic (2006). The findings of the commission revealed that following World War II, due to the pressure of the Soviet Union, the Communist Party gained power in Romania, instating a Stalinist totalitarian dictatorship based on terror and the annihilation of the rule of law and pluralism by show trials and frauds as well as by the elimination of the social strata considered "class enemies" (i.e. the bourgeoisie, the nobility, the peasantry, the intellectuals, or the students). Tens of thousands of people were imprisoned on political grounds; abuses, assassinations, tortures, and executions were committed.

The transformation of the society was carried out through fear and massive propaganda having in view the instauration of a despotic political system led by the only Party, and a caste profiting from it gathered around the supreme leader, the

1 The novel consists of 230 chapters and appeared in sequels in the periodical Viața studențească [Student Life] before 1989, under the pseudonym Ars Amatoria, the name of a group whose soul was Ioan Groşan. The plot is set at the beginning of the $17^{\text {th }}$ century, presenting a series of travels and intrigues. Voivode Barzovie, the banished ruler of Moldavia, followed by Vulture, his sword-bearer, and Broanteş, the rhapsode, travels to Istanbul to seek help for regaining his throne. In the meantime, two monks, Metodiu and Iovănut,, are appointed with the secret mission of conducting negotiations with the Papal Court to form an anti-Ottoman alliance.

2 Romanian literature operates with several labellings of the cultural and literary periods, one of which being the decadal division. Writers of the ' 80 s are usually associated with Postmodernism.

3 Translations from Romanian literature and specialist literature were made by Árpád Kémenes throughout the article. 
General Secretary of the Communist Party. After a brief opening to the West and a relaxation of the internal repression, at the turn of the 1960s-1970s, when Nicolae Ceauşescu became leader of the Party and of the country, a new period of closure and repression followed, which lasted until the 1989 revolution, when Ceauşescu was executed. The Communist regime was restrictive on freedom of speech - making use of censorship, ${ }^{4}$ interceptions, and spying - and on the freedom of leaving the country, while those who expressed their discontent or attempted to defect from the country were considered traitors, the protesters being humiliated and arrested. The prosecution of ethnic, religious, or cultural minorities and of those who had a different sexual orientation targeted the expurgation and homogenization of the masses of people, trying to create a unitary nation-state with downtrodden citizens easy to manipulate. During Ceauşescu's leadership, the heads of the ideological apparatus propagated xenophobia and the idea of protochronism, ${ }^{5}$ introducing the cult of the leader's personality.

For most writers, this period is a battle to create enclave-like spaces for free manifestation, it is "the story of a struggle to reconquer a space for the production of genuine cultural values and to create counter-institutions to protect these, followed by a desperate defence of that space and those values from the Party leadership's relentless assault" (Verdery 1991: 110-111).

In the early 1980s, there arose the generation of self-reflexive writers, who reshaped literature and shared a common programme, paying tribute to Postmodernism on the way. It is a generation which - due to the political context - could not totally express itself, "whose full political and aesthetic implications could not be articulated before 1989. It was only after the fall of Communism that the writers of this group overtly adopted and theorized the term Postmodernism for their preexisting literary agenda" (Spiridon 2004: 69).

Having to face the problems imposed by a totalitarian regime, this generation needed to use different strategies, tactics, and devices to avoid censorship and promote the aesthetic coordinate by "embracing relativism and structural eclecticism" (Spiridon 2004: 69), creating thus a literature which was incongruent with the official metanarrative. Hence:

the young authors were accused of being decadent, hypertechnical, caught in textualist games, but the unspoken real reason for putting them on trial [...] (some [...] literally) ${ }^{6}$ was the subversive anti-totalitarian drive of their literature. Hence, the striking discrepancy between the alleged technical

$4 \quad$ Between 1965 and 1971, during the first years after Ceauşescu's ascension to power, there was an attenuation of censorship, the leader's official attitude being one of disapproval towards the Soviet Union.

5 It is a term related to Romania, which covers the basic national ideology manifested under Ceauşescu.

$6 \quad$ Not only in the '80s. See the Black Church Trial (1958), for example. 
artificiality of their literature and the strong political reactions they elicited from their censors. (Spiridon 2004: 69)

Therefore, the solution chosen by the generation of the ' 80 s was to eliminate all kinds of anterior models, such as the West-East antipode, and to find a new, innovative identity, which "emphasized hybridity and cross-fertilization of models" (Spiridon 2004: 69).

Due to its geographical position and, as a consequence deriving from it, the social and political situation, Romanian culture - including literature as well - is a contact culture, an aspect of which is, among others, an interference ${ }^{7}$ of the West - representing "confidence in progress, rationalism, historicism, individualism, secular spirit, the cult of originality, and commitment to a capitalist economy" (Spiridon 2004: 67) - with the East - "overrating of primitivism, exoticism, anachronism, authenticity instead of individualism, Orthodoxist spirituality, phobia of capitalism, and fatalism" (Spiridon 2004: 67). These antinomies became part of the Romanian identity, giving birth to literary genres, topoi, stereotypes, and clichés which can be both positive (the use of multiple sources and models) and negative (giving birth, sometimes, to confusion).

Categories of West (Occident) and East (Orient) have been present throughout Romanian literature since its very beginnings, ${ }^{8}$ gaining particular importance in the $19^{\text {th }}$ century, occupying a well-defined role in the literature of the late $20^{\text {th }}$ century, and having a well-defined theoretical, historiographical ${ }^{9}$ as well as literary significance in the $21^{\text {st }}$ century, too.

Thus, the choice of an alternative universe, able to abstract from reality and to surpass the problem of the system and censorship, but which is at the same time familiar to the Romanian audience, finds a solution in the East-West ${ }^{10}$ antinomy, metamorphosed in hybridity, for which, among others, Ioan Groşan's novel One Hundred Years at the Gates of the East is an illustrative example not only due to the characters' travels to the East (Istanbul) or the West (Vatican) but also because of blending the features characteristic of the two worlds (e.g. the Tatar student in Padua).

Hybridization - the seventh feature of Hassan's catena of postmodern features, his “paratactic list” (1986: 504), alongside Indeterminancy, Fragmentation, Decanonization, Self-less-ness, the Unrepresentable, Irony, Carnivalization, PerformanceParticipation, Constructionism, and Immanence - is "the mutant replication of genres” (1986: 506). Hassan also speaks of a "different concept of tradition, one in

$7 \quad$ See Verdery (1991).

8 Cornis-Pope (2004c: 499) points out that the categories of East and West can be traced back to the beginnings of Romanian historical fiction: Istoria ieroglifică ( A History in Hieroglyphs; 1705) by Prince Dimitrie Cantemir of Moldavia and Țiganiada (The Gypsiad; 1800-1812) by Ioan BudaiDeleanu.

$9 \quad$ See Djuvara (1995).

10 The concept of the West was considered undesirable after 1945. 
which continuity and discontinuity, high and low culture mingle not to imitate but to expand the past in the present. In that plural present, all styles are dialectically available in an interplay between the Now and the Not Now, the Same and the Other” (1986: 506).

From Hassan's highly discussed catena, hybridization became a focal point also for Homi K. Bhabha. Out of his detailed observations, from our point of view, his association of the term with power is particularly important; he sees the effect of colonial power as the production of hybridization rather than "the noisy command of colonialist authority or the silent repression of native traditions" (Bhabha 1994: 112). If accepted, it can be observed that "the ambivalence at the source of traditional discourses on authority enables a form of subversion, founded on the undecidability that turns the discursive conditions of dominance into the grounds of intervention" (Bhabha 1994: 112).

Any kind of hybridity the generation of the 1980s adheres to emphasizes one of the basic features of "minor literatures", where Romanian literature also belongs, namely that - owing to their peripheral position - they tame the models borrowed, adapting them to the local context, obtaining new, milder forms.

\section{The author}

\subsection{Context, relationship with Postmodernism, intention, and strategy}

Groşan belongs to a literary generation formed in a "small marginal culture" (Spiridon 2004: 70), in an oppressive social and historical system, and for whom Postmodernism offers means to rebel against the system. Thus, the context contoured above provides explanation for the type of novel elaborated in the sense adopted by Dekoven:

In order to understand what has made possible certain novelistic forms that are culturally powerful at any given historical moment, it is necessary to look at the culture surrounding the production of that novel and to do so in a way that takes into account the historical conditions that in turn produced or made possible that particular cultural configuration. (2009: 334)

The question is what the possibilities of a cultural producer are in such conditions, in a historical moment in which "meaning is produced and controlled" (Verdery 1991: 87). In our view, the position of the writer as a cultural producer has to be approached analysing the writers' relationship with censors, "who call into question everything from words used to the artist's judgement in framing a story" (Verdery 1991: 88). This relationship could have several coordinates: it was possible for the writer to work for the censorship, to write about the regime either in a way 
allowed by the censors or circumventing the censorship. The last approach offers several possibilities: rewriting the parts "recommended" by the censors or avoidance through "codification" ("acceptable" topic, metaphors, allegories, parody, etc.).

The relationship mentioned above is further complicated if the chosen topic is history, which "is largely a construction that does not withstand the test of either credibility or verification" (Sicher-Weinhouse 2012: 180). The writer could not adopt a topic that dealt with contemporary history - namely the Ceauşescu period - in a straightforward manner if it did not align with the official ideology, and "the control of history remained a priority of party propaganda well into Ceauşescu's postStalinistic regime. While historical novelists were allowed to experiment formally, their 'rereading' of history was closely monitored by censorship" (Cornis-Pope 2004b: 501). Anyway, postmodern historiographic metafiction was a good solution because "the interaction of the historiographic and the metafictional foregrounds the rejection of the claims of both 'authentic' representation and 'inauthentic' copy alike, and the very meaning of artistic originality is as forcefully challenged as is the transparency of historical referentiality" (Hutcheon 1988: 109-110), giving thus to censors other things to mind about.

Ioan Groşan is fundamentally a humourist, in whose oeuvre "plebeian humour, gross satire alternate with 'high' genres: fantastic fiction, metafiction, etc." (Cărtărescu 2010: 428), and who creates

the most didactic texts of metanarrative postmodernism belonging to the fiction of the '80s. [...] In his later writings, Groşan parodically 'recycles' the historical novel - One Hundred Years at the Gates of the East -, the SF Planet of the Mediocrities -, and the erotic novel - Nutzi, the Scarecrow of the Constitution -, but the postmodernist spirit of the first volume gets gradually thinner because parody, humour, and satire do not usually get beyond their classical limits despite the avalanche of allusions and heteroclitic quotations. (Cărtărescu 2010: 428)

The fascination of the writers of the 1980s for marginal forms of prose lacking cultural prestige, such as the historical novel or SF, is explained by Cărtărescu through the fact that these genres provided them with "rigid narrative structures easy to manipulate as well as archetypical images that were suitable for ornating fictions, like a game with marbles" (2010: 433), and also with one of the functions analysed above: "a special function to protect the ideological discourse from censorship. Placing some of the events into the past and camouflaging satire with a picturesque prop could make censors overlook even virulent pamphlets written against the Communist establishment and, during the last decades, against Ceauşescu's despotic dictatorship" (2010: 433). Even if this function was preserved in the historical novels written by the generation of the 80s, Cărtărescu argues that 
this function has just a secondary role compared to the adherence to postmodernity, which - to their luck - hands on a plate a range of subversive devices. He also points out that these authors, together with Groşan, use historical conventions in a particular way because the constructed "real" eras - devoid of time - are, firstly, an excuse for introducing false perspectives and narrative loopings (2010: 427-434).

As a writer, Ioan Groşan did not have - even if he had wanted to - the possibility to remain neutral in the historical and cultural situation outlined above. Thus, in his novel One Hundred Years at the Gates of the East Groşan creates - through humour - a historical and parodical (meta)novel, a hybrid where one can identify the intention - associated with the novel by Amigoni - to "ask its reader to entertain instead more sceptical and playful questions about the relationship between narration and our knowledge of life, reality and history” (2000: 129).

\subsection{Main instrument - The humour}

If the system forms its own intellectuals, there is always a counterpart that uses the same weapons. Of all the weapons used by the system, we are primarily interested in language. The intelligentsia who fought the system found in language an aspect which they could use as a weapon, namely the humour.

Humour is one of the most effective literary weapons to please the audience, as it develops characters and makes plots useful and memorable. [...] It arouses interest among readers, sustains their attention, helps them connect with the characters, emphasizes and relates ideas, and helps the readers picture the situation. Through this tool, writers can also improve the quality of their works by pleasing the audience. Apart from that, the most dominant function of humor is to provide surprise, which not only improves quality, but improves memorable style of a literary piece. The writers learn how to use words for different objectives. (Hyman 2019: 31; emphasis in the original)

So, not only does it have the capacity and role to assert life and identity, catharsis, entertainment, amusement or - as we saw above - to avoid censorship and undermine authority, but it also contributes to help evasion and the creation of shields or - on the contrary - to spark out conflicts. All these, of course, are in line with the author's intentions, who is able to create and raise everything from a micro, individual level - in our case, that of a writer living in a totalitarian regime, who wants to evade into another reality and/or lead the reader into an alternative world where, with humour, he can reach catharsis, having thus both therapeutic ${ }^{11}$ and compensatory goals - to a macro level - where the author intends to use humour to highlight a number of social and historical flaws and follies.

11 See Stephenson 1951. 
Concerns related to the definition and clarification of the concept of humour can be identified in European culture as early as in Plato's and Aristotle's works. Humour is the result of a number of complex factors determined by historical time and individuality, with roles, effects, and application in psychology, culture, sociology, and geography. Some even claim that there is communication between man and computers, where computers would be able to generate humour (Țifrea 2008).

Humour's ubiquity in space and time raises the problem of its definition, humour being - like many other concepts and phenomena - a very elusive category, a manifestation that continuously eludes attempts to provide it with well-defined contours, as shown by Farber, who states that:

humor remains somewhat mysterious and elusive. Or not even that. It may be that most people, even teachers in the arts, bypass theory entirely and simply accept humor as a given: an unanalyzable fact of human life. I've sometimes wondered if it may be that we don't want to understand humor, either because we're afraid that this understanding will spoil the game or, just possibly, because we sense that, as a consequence of it, we may discover things about ourselves that we would prefer not to know. (2007: 67)

Basing on the same idea, Eduardo Jáuregui Narváez (2014) explains that each theoretical school which dealt with humour concentrated on certain aspects of laughter, excluding others, elaborating a reasonable description of a limited part but without managing to understand the authentic nature of the whole. Some of the scholars, frustrated with so much futile flurry between less plausible theories, have decided that there is not one single cause of laughter. Instead, there are different types of humour. The problem is that there is no consensus as far as its number and types are concerned.

In this complexity, humour research ${ }^{12}$ has presented three basic theories, none of which having proved to be fully adequate: (1) the superiority theory, present from classical times, from Plato and Aristotle until the end of the $17^{\text {th }}$ century; (2) the relief theory, associated with Herbert Spencer and Sigmund Freud, with two scenarios: "First, the laughter may release some pre-existing nervous energy, or second, the humorous stimulus may itself cause the build up of the nervous energy and then relieve it. [...] In the second scenario mentioned above, the energy released in laughter is energy which the humorous stimulus - say a joke or cartoon - has built up itself" (Morreall 2008: 222); (3) the incongruity theory (deriving from Aristotle and Cicero, taken over and further developed by Kant, Schopenhauer, and Kierkegaard), which has been present in different forms since the $18^{\text {th }}$ century.

12 One of the first steps in this direction, according to Morreall (2008: 221), is Lord Shaftesbury's 1711 essay The Freedom of Wit and Humour. 
Despite the fact that it dominates today's humour theory, this last theory is still widely regarded as not a complete, exhaustive theory.

None of these three theories - considered traditional - can be viewed as satisfactory, a fact proved by their hybridization, by the multitude of research studies that aim to sustain the idea or to offer possible solutions, even attempts to create new theories. ${ }^{13}$ Apart from the definition, each researcher tries to label the types and sources of humours and to divide them into classes. Thus, we can talk about verbal or non-verbal humour, primitive or high/elevated humour, universal and local, derisive humour, empathic humour, and counter-restriction humour with its subcategories - aggressive humour, sexual humour, and nonsense humour, though there are others, too, such as scatological humour, which play a role in the arts (Farber 2007: 72-84), or bawdy or ribald humour, parental or genealogical humour - called "device” by Stamm (1959: 482).

Similarly, the various devices of humour must also be mentioned, such as absurd, ambiguity, bathos, caricature, carnival, coincidences, comédie noire, confusion, double entendre, exaggeration, excess, extraction, hyperbole, incongruity, intertextuality, irony (verbal, situational, dramatic), juxtaposition, litotes, ludic, malapropism, mistaken identity (twins, names), over- and understatement, oxymoron, paradox, parody, pathos, pun, sarcasm, satire, sensorial (over-) stimulation (visual, aural, etc.), slapstick, stereotype, substitution, surprise, taboo, and so on, ${ }^{14}$ many of which being regarded characteristic features of certain genres. ${ }^{15}$

There is also a wide range of subject matters, such as society (social classes, ethnic or racial minorities), history, politics, and so on, but, generally speaking, "in all cases, a consistent stereotype of these positions in the stratification system is developed" (Stephenson 1951: 571); in our case, history - the past that is sufficiently distant for not raising the problem of the allusions to the present.

\section{Audience}

If we talk about the author, we must also mention the audience, the Reader, because, despite the myth according to which "serious artists don't pay attention to their audiences but instead focus only on expressing their visions [...] it's impossible to make meaningful rhetorical choices without some sense of whom you are addressing - about their beliefs, background knowledge, values, taboos, sense of humour" (Phelan-Rabinovitz et al. 2012: 140).

We regard the audience not from the point of view of narratology, because we do not aim to exemplify concepts as actual, implied, authorial reader, etc., but

13 See Morreall 1983.

14 Quintilian identified over 200.

15 For example, the picaresque novel. 
rather have in view the flesh and blood reader from the perspective of the context presented above, the situation of a socio-political reader in a totalitarian system and his relationship with the postmodern novel, more exactly, that of Groşan's. Besides its social role of shaping identity, humour also had a cathartic role in the life of the reader in the totalitarian system.

As regards the first steps of the Romanian audience in its relationship with the genesis of the novel, Cornis-Pope identifies the reading public as being the weak link: "At the beginning of the nineteenth century the reading public was composed still of landowners and clergy, whose reading tastes had been formed by religious and didactic literature. By mid-nineteenth century the reading public included also tradesmen, craftsmen, functionaries, officers, and middle-class women" (2004b: 442). In the $20^{\text {th }}$ century, a diversification of the audience took place; they became more and more familiar with the novel (having its roots in the $19^{\text {th }}$-century novels). However, during the second half of the $20^{\text {th }}$ century, readers turned away from the grand narrative structures. In our particular context, we refer to an audience influenced - like the author himself - by the context of a totalitarian regime. This type of socialization can be identified even during the first years following the 1989 events, when the analysed novel appeared for the first time in a book format (1992). In his study The Search for a Modern, Problematizing Historical Consciousness: Romanian Historical Fiction and Family Cycles, Cornis-Pope shows that the number of family cycles and epic historical novels is scarce after 1989, the reason being that "writers emerging from Ceauşescu's peculiar brand of national communism, have understandably little faith in grand narratives - those of nationalism included" (2004c: 504).

The primary audience in our case is the Romanian one, and it has to be, first of all, a connoisseur - not only but necessarily - of the Romanian context, society, history, politics, and, last but not least, of Romanian literature because they have to "decode [...] concepts: their meaning will always depend on the precise culture they are part of" (Spiridon 2004: 70). So, the reader of Groşan's novel was supposed to have certain social, cultural, political, cultural, and - above all - literary knowledge to be able to discern and understand the author's intentions and the devices he uses in this particular book and to be ready to get involved in the dialogue initiated by the author. In this regard, we speak of an educated reader, able to interpret and also read between the lines, an ability developed also due to the totalitarian system and censorship, as remarked by Cornis-Pope: "One positive outcome of this confrontation with censorship was the emergence of several generations of subtle if oblique writers and of alert close readers, looking for hidden political references" (2004a: 41), residing in a strong bond between author and reader, the first to express the forbidden and the latest to discover the hints, "an art perfected under communist censorship" (Vianu, qtd. in Cornis-Pope 2004a: 41).

Of course, one can never talk about a completely homogeneous subclass - because within a language readers can be categorized into different subclasses based on 
gender, ethnicity, religion, etc. -, so they are projected into a generic class, educated and bonded by the socio-political situation.

\subsection{Horizon of expectations}

In this context, this audience with bifocal glasses and different reading strategies is to a certain extent prepared for their horizon of expectations - activated with each appearance of a literary work, as put by Jauss (2005) - to be deceived, which is exploited to the full by Groşan. Our writer deceives expectations in all possible ways, using the devices offered by postmodernism in a totalitarian context, his main weapon being humour and its devices.

Humour can be turned into a weapon because "by its nature tends to seek out and reveal incongruities" (Farber 2007: 84). Incongruous elements can be found throughout the novel, the link between them having the obvious role of triggering a certain humoristic state. In order to present the sources and devices of humour the audience can find in Groşan's novel, we would like to offer the filter proposed by Farber (2007), which explains the relationship between incongruent elements and humour. It explains the system with psychological incongruous counterpositions, which are external ( $\mathrm{A}$ and $\mathrm{B}$ ) and internal ( $\mathrm{a}$ and $\mathrm{b}$ ), where $\mathrm{B}$ is the strong need or inclination and A internalized constraint or obstacle. On an analogical level, Farber shows that "when the linked, incongruous A/B in the humorous situation suddenly and temporarily alters the relationship between a pair of well-established counterpositions in the perceiver [...], and does so in a way that keeps both of these counterpositions in play, something happens that can be compared [...] to current flowing across a spark gap" (2007: 72). He says that in a humorous situation the A is not eliminated, replaced by the B, but that it is successfully opposed by the $B$, namely "undermined or circumvented or defied or contradicted. What makes humour work is the temporarily altered relative status of the two counterpositions in the perceiver, and for this it is essential that, in the humorous situation, the A must somehow remain in place so that, in the perceiver, the restrictive or blocking counterposition continues to be evoked" (2007: 70-71) and has the result "that, within the perceiver, a need temporarily succeeds, not in eliminating, but in defying the restriction that governs it" (2007: 71).

\subsection{What the audience gets}

Humour as a weapon for cracking reality and undermining a horizon of expectations is used by Groşan in several aspects, the incongruences and contradictions being grouped into several categories: composition, frame (space and time, situations), identity (social status, names, physical appearance, ethnic and religious belonging), and language. 
As far as the elements of composition are concerned, one can highlight the problem of titles and the specificity of the text. Before getting acquainted with the text itself, the reader makes a connection with the title of the novel, One Hundred Years at the Gates of the East. This is a clear allusion to the emblematic novel of magic realism, One Hundred Years of Solitude by Gabriel García Márquez and to Mateiu Caragiale, who quotes in the motto to his novel Craii de Curtea Veche (Gallants of the Old Court) a French diplomat named Raymond Poincaré - "Que voulez-vous, nous sommes ici, aux Portes de l'Orient, où tout est pris à la légère." [What do you want, we are here, at the Gates of East, where everything is taken lightly.] This "will become, as the plot unfolds and branches out rhizomatically, a pretext for the narrator to make fun of trouble, simultaneously deconstructing a series of commonplaces, stereotypes of identity, prejudices and literary clichés" (Popa 2017: 198). In a similar fashion, the titles of the episodes also introduce a number of notions, such as allusions to the problems of a capitalist society (Ltd.), problems of everyday life (Days Off), ironic or interpretative transtextuality: $A$ Weaker Episode, Without a Title, Gothic Dialogue, The Second Gothic Dialogue, The Last Gothic Dialogue, The Teachings of Metodiu to the Newly Married, ${ }^{16}$ The Sorrows of Young Cosette. ${ }^{17}$

Apart from the episode titles, intertextuality can be captured throughout the text, where one can identify distorted elements taken from the ancient times, blending the elevated with the mundane: "An old Asian saying: Inter arma silent musae" (Groşan 2012: 9); “Animi volant, corpora manet, as the prophets said!” (Groşan 2012: 9), "some letters from the considerable pile gathered over time addressed to Ars Amatoria"18 (Groşan 2012: 326) - the title of Ovid's work becomes connected with TV series; Horace: "Oh the times, stop a bit!" (Groşan 2012: 78); but also from other periods such as the One Thousand and One Nights (like Scheherazade, Cosette told the sultan stories every evening), Shakespeare: "A Romeo soaping himself in front of the mirror" (Groşan 2012: 97), Don Quixote: "valiant Phoebus [...]" (Groşan 2012: 27), Kant: "A cricket could be heard here, an ant there, above them was the starry sky" (Groşan 2012: 27); Stendhal: "the epic threads of a traditional narration (which is nothing but a mirror carried during a long journey)" (Groşan 2012: 308); Dostoevsky: "a Karamazov asking for some suspenders" (Groşan 2012: 97), ironic allusions to feminism, propagated by Virginia Woolf: "If born later, in our century, for example, and not in the middle of the reed, she could have easily become a pilot, a mountain climber, a writer, a tram driver, and actress or a film chronicler. [...] Nothing, alas, nothing of the sort; only the reed, the smell of mud, the flock of

16 Reference to the title of a Romanian Mediaeval literary work: The Teachings of Neagoe Basarab to His Son Theodosie ( $16^{\text {th }}$ century).

17 Allusion to The Sorrows of Young Werther by Goethe, Cosette being a character in Les Misérables by Victor Hugo.

18 The pseudonym he signed the episodes of the novel with when they appeared in a periodical before 1989. 
children and the sulky man, who beat her half dead on a weekly basis" (Groşan 2012: 207), or references to Kundera (Groşan 2012: 353).

Pastiche of Romanian literary works can be found throughout the novel. The Romanian reader can find references to elements of both folk and written literature, from the chroniclers ("we are coming from Rome") to the generation preceding Groşan. For example, the Tatars sing "We glorify thee, glamorous Baikal" (Groşan 2012: 12) - an allusion to the lyrics of the old national anthem "We glorify thee, Romania” or in the episode titles (Episode 22 bears the title of Dimitrie Cantemir's work Descriptio Moldaviae, Episode 23, Halt at Topos refers to Tales from Ancuța's Inn by Mihail Sadoveanu). One can identify the postmodern intertextual game on quotations with deliberate false references or without references at all such as in Umberto Eco: "Sweet and beautiful is the language you speak" says Vasea to Metodiu (Groşan 2012: 167), a quotation transformed into the singular taken from the poem Limba românească (The Romanian Language) by Gheorghe Sion.

Analysing intertextuality, we can also mention the use of distorted adages such as the allusion to the slogan of the 1789 French Revolution or, again, to the title of the novel by Gabriel García Márquez: "Where did our good Metodiu take his strides [...] after Iovănuț [...] had remained in the Eternal City to share with us the truth of the words ex occidentae lux? Let us not give a straightforward answer, we'd better make slow hints, having at disposal one hundred years of fraternity, equality and solitude” (Groşan 2012: 330).

The text is characterized by fragmentarism, a feature of Postmodernism, which, in order to become a source of humour, also plays on deceived horizons of expectations (for example, contrary to expectations, the episode entitled 7 Days Sick-Leave does not describe health problems, even more, besides the title of the chapter, it contains not a single word) and also by ironic transtextuality, where the audience can recognize some characteristic features of the historical, gothic, adventure, and picaresque novels, such as those written by Voltaire, or some forms like, for example, that of the serial with episodes. ${ }^{19}$

Regarding the frames, two main axes can be identified: that of the actions and events (including the ones proposed by the author in the novel) that can be placed by the reader on any coordinates of time and space (the 1600s, Moldavia, the Ottoman Empire, and on the way to the Vatican) as well as frames that, although they appear in a certain time and place, are interpretable through allusions and distortions.

The first, narrower category will be illustrated with two examples. The enumeration of the humble food the two monks are having ends unexpectedly: "their lunch was simple: two sorrel leaves, three dry plums, a lump of cold polenta, an onion and a hastily caught rabbit" (Groşan 2012: 5). Another scene describes the meeting of the couple in love, Broanteş and Cosette, the writer arousing certain expectations in the reader, who thinks that an intimate love scene will follow: "We 
are in Cosette's room, the fire is silently crackling, the sun has duly set outside, the light of flames is flickering on the walls, furniture has dozed off, the four-poster bed is fast asleep on its four legs, Cosette has told her story and her prayer, and now she is looking at Broanteş under her eyelashes [...]" (Groşan 2012: 97). And now the narrator's confession follows: "we'd rather state it firmly, dear Reader, that we do not know what went on after that in Cosette's room" (Groşan 2012: 98).

The second category comprises the historic events that undergo unexpected reinterpretations. For example, the Battle of Mohács, where the Kingdom of Hungary was seized by the Turks, appears as an act of unrequited love, the old Tatar being in love with a Hungarian girl, as the tattoo on his shoulder betrays it: "Youlishka Mohach, 1526" (Groşan 2012: 11). If we further analyse the idea of the lost fatherland, we also have to mention one of the main characters of the novel, Voivode Barzovie, who loses his throne and goes to Istanbul in order to find out the reason and try to regain it. ${ }^{20}$ When he got home and unboarded the ship, Voivode Barzovie wanted to kneel down and kiss the soil of the fatherland, but he falls in the mud. The grotesque of the situation is yielded by the contradiction between the noble ideas behind the pathetic gesture and the abject reality. "Sublime but awkward movement: having lost his usual centre of gravity in the massive area of his stomach, his most illustrious body falls on its side, and, for a couple of moments, Voivode Barzovie, as he was kicking with his hands and legs, looked like a Slavic Gypsy. He wanted to stand up, but the mud was not scarce" (Groşan 2012: 197). The comparison emphasizes the character's helplessness; the hyperbole "his most illustrious body" combines two spheres: an ethical and a rough, quantitative quality referring to the character's obesity.

It goes without saying that the historical moments do not refer only to the Middle Ages but also to the realities of the $19^{\text {th }}$ and $20^{\text {th }}$ centuries, with references to the totalitarian regime ${ }^{21}$ (the title of Episode 49 being "the Censored Episode", the term "comrade" or the blackbird with direct reference to espionage), or "The West reaches as far as this, from here it is the pashalik" (Groşan 2012: 331) - an allusion to the slogan coined by the residents of the city of Cluj: Democracy reaches as far as this, from here it is Mănăştur, ${ }^{22}$ or the parody of some contemporary radio programmes such as "Response to our readers/listeners", where the question asked

20 The truth behind it is that for several centuries rulers of the Romanian states, Wallachia and Moldavia, needed the Turks' consent for ascending the throne, which was granted in return for money.

21 A special subcategory of the frame is the large number of references to the totalitarian regime - some of which have already been referred to - regardless of whether they refer to events, practices, spaces, or language.

22 A district of Cluj-Napoca that supported the 1946 student uprising, being one of the main centres of resistance against the instauration of communism in the region. At the beginning of the communist era, the village gained notoriety because at the entrance the residents displayed a banner with the slogan quoted above, "democracy" referring to the dictatorship installed by the communists. 
by the reader does not have the slightest connection with the plot of the novel. The absurdity of the situation described by the reader reveals the decision-making bodies' total ignorance of reality.

Alexandru Constantin, Întorsura Buzăului: we honestly thank you for your nice appreciations of the serial. They touched our hearts. As far as the reason of your letter is concerned - unfortunately - we regret to have to say this you can't do anything, that's what it is: according to the regulations in power, in cases like this, the tax on your pasture that disappeared due to a landslide, and on the place of which a fishpond appeared, has been established based on the quantity of fish you claim not to exist in your newly formed lake. (Groşan 2012: 326)

The novel bears the features of political satires owing to the allusions to dictatorial politics that transcribes history according to its own interests. We find out about Sultan Beşiktaş Mehmet Hamza that "In 1656, after the Battle of Szeged, he gets a scholarship to Vienna." The Siege of Vienna is anachronistically associated with a concept specific to the age when the novel was written. He "returns to Istanbul, seizes power, moves into the palace and organizes a national referendum through which he is elected Sultan” (Groşan 2012: 56). ${ }^{23}$ Cosette, the Gypsy girl, says to Broanteş in order to calm him: "Nomadic peoples are those that are unable to control their sensations within a given historic perimeter. Take, for example, the poor Pechenegs: valiant each. Who would dare to think of assimilating them? And what remained after them? Two bracelets and - don’t forget it - a Slavic paperclip!” (Groşan 2012: 91). The last sentence is an ironical allusion to the way communist historiography attributed aleatory identities to the artefacts found by archaeologists. Inverted logic resembling Soviet propaganda also appears. In Episode 225, the Turk janissary says: "Who gives anything to us voluntarily? It is lot like it used to be, when one was willingly or unwillingly - brother with the Turks. Now people know us: 'a Turk' they say, and run away. They only leave the sick, the cripples and the traitors behind, whom we clear away" (Groşan 2012: 351). As a result of this, downtrodden peoples have become stronger and healthier. And, last but not least, the ironic imitation of the wooden language, the propagandistic style characteristic of the communist period should be mentioned: "our contemporary perspective on history, a perspective in which the concept of critical realization of the past's heritage continuously gains new valences" (Groşan 2012: 20) or exhibiting communist slogans such as "the fight for peace” (Groşan 2012: 10) - "Beşiktaş Mehmet Hamza was fighting for the reduction of the number of battles, for launching them after having reached mutual agreement, for setting humane, reasonable tributes" (Groşan 2012: 56). Progress in the Ottoman Empire was reached through counterfeited products, the style being the parody

23 Procedure used in communist dictatorships for gaining legitimacy. 
of the CMEA reports on communist achievements: "A large number of handicraft workshops have been established, where Toledo swords were manufactured based on a Turkish procedure. Murano mirrors were produced in Plevna [...] The average Turks' longevity and the number of wives have increased" (Groşan 2012: 56). Cosette is made to write a declaration on why she wants to become a Turk, an allusion to the practices of the communist secret police to recruit informers. "I was sitting with a sheet of paper in front of me, where I was supposed to write why I wanted to become a Turk, and I didn't know what to write. My mind didn't want to, but I felt fear inside. That Turk, seeing that we weren't writing anything at all, started to dictate why we wanted to become Turks" (Groşan 2012: 91).

Also, there is a large number of narrative, temporal, and special anachronisms. The narrator shifts his temporal position: "The $17^{\text {th }}$ century is far away, the $21^{\text {st }}$ century is near" (Groşan 2012: 353) and talks about tractors, blocks of flats, apartments.

The characters' identity is referred to by resorting to a wide range of categories: social status, names, physical appearance, ethnical and religious belonging.

Postmodern constructions of identity tend to discard mononuclear and homogenous categories in favour of multiple versions of alternative ethnic, gender, spiritual, or sexual self-identification and affiliation. With the collapse of the nuclear family, the breakdown of master-narratives of nationhood, and the spread of a multiethnic and multicultural society, the "Other" has come to the fore as a subject of racial, ethnic, religious, and ideological tensions, while the "self" has become marginalized and fragmented. (SicherWeinhouse 2012: 183)

However, on the first pages, one can already find a (contradictory) physical description of the characters, for example, that of Iovănut, the monk, in Episode 1: "The second silhouette seemed shorter, but at a closer inspection it looked as if it was an unusually tall young man" (Groşan 2012: 5). Physical traits are completed by names, which are telling names, such as Barzovie (stork, migratory bird), swordbearer Vulture (animal of prey), Sultan Beşiktaş (the name of a sports club in presentday Turkey). The characters' features are captured not only through their names but also through a variety of epitheton ornans such as "the silent Broanteş", who later turns out "to have undergone the trouble that is known among the people by the phrase 'his tongue was cut out"' (Groşan 2012: 24). The harsh reality is attenuated by the comic and unexpected contrast because the expression usually refers to a talkative person, while Broanteş, the chronicler, is not silent because he does not want to talk but because his tongue has been brutally cut out. The heroes' characters are revealed by a number of identity problems linked to the family, where a brother killed by the other brother reappears, the encounter being a happy one. Thus, the reader experiences anamnesis, the rediscovery of the known, in the Platonian sense, 
where the known entity reappearing in new conditions offers the receiver a feeling of satisfaction. Groşan reaches this through a game on the ballad Mioritza, one of the fundamental texts of Romanian national identity, complemented with some Caragiale, Sadoveanu, and Rebreanu. The same scene also illustrates that "in the $17^{\text {th }}$ century you could not just simply pass the Moldavian border; after you proved you knew the watchword (some lines from the testament of the shepherd from the Mioritza), you had to declare your identity" (Cliveț 2001: 90).

As far as the characters' identity is concerned, the author deconstructs or distorts - mostly by means of (self-)irony - a number of stereotypes, for example, those linked to nationality: Metodiu finds a printing press in the Tatars' harem used for multiplying psalters and homilies; a Turk says: "Overall, we are not clever, there are also proverbs on this, but while others were making proverbs about us, we made conquests with them" (Groşan 2012: 342). People belonging to different nationalities meet at the inn Topos - the name referring to Tales from Ancuța's Inn by Mihail Sadoveanu -, the gathering place of the representatives of different nations.

Distortion, which can be termed "stolen" identity, has also the role of making readers smile: at the border of the pashalik, the Turk is singing a Hungarian song, “Ozoseip, ozoseip”"24 (Groşan 2012: 331), or the Romanian orthodox monk, Metodiu, having arrived at Buda, can hear "Ottoman merchants shouting 'Kürtős kalács!'”25 (Groşan 2012: 356), and, instead of the traditional greeting, in the south of Moldavia, guests are welcome with the slogan "Welcome to the beautiful land of the Tatars!" (Groşan 2012: 19).

The problem of identity is extended over cultural and literary aspects as well. Groşan approaches with irony the didacticism of the $19^{\text {th }}$-century Romanian literature, the narrator urging the reader to complete, in his imagination, the unfinished episode, presenting a sketch in which the author mocks at the autochthony of this literature. In the plan of the ideas that the reader is supposed to follow, the following is included: " 1 . At the beginning, a Doric complex sentence containing three clichés of our cultural memory and the clearly expressed idea that in the $17^{\text {th }}$ century there were just a few nations that had scholars of a stature comparable to Udrişte Năsturel's” (Groşan 2012: 137).

And, finally, regarding language, one can identify several devices and techniques used by Groşan. We can encounter an unexpected mixture of languages. The title of Episode 71, "Iassy et se habitants ${ }^{26}$ va leato seven thousand and a bit more", is a good example of hybridity: half of it is in French, recalling the French travel fiction written in the Century of Light, and the second part reminds the reader of Slavonic Church language and of an archaic chronology; or "'What's this?', muttered Metodiu

24 Distorted transcription of the Hungarian folk song "az a szép, az a szép".

25 A typical Hungarian sweet.

26 Iassy et ses habitants en 1840 [Iassy and Its Habitants in 1840] is the title of a $19^{\text {th }}$-century writing by Alecu Russo. 
pointing to the machine. 'A printing press, monsher!' explained the young khan" (Groşan 2012: 10). The humour stems from the fact that in the $17^{\text {th }}$ century a Tatar speaks French, but there is also reference to the Romanian cultural situation in the $19^{\text {th }}$ century, when the language used by the Romanian élite (and not only) was the French. This aspect was used as a device for humour by the $19^{\text {th }}$-century Romanian writers, too, in order to parody the ascending ranks of society that used broken French to imitate the members of high bourgeoisie and aristocracy.

The category of language also includes the mixture of different stylistic registers, of archaisms and neologisms in order to create anachronisms, for example: "Don't shoot, comrades!"; "The Lord gave and the Lord has taken away - sighed the old man crossing his legs Turk-fashion. [...] Let us give the body its due because without it soul isn't more than nothing” (Groşan 2012: 5); in Episode 221, captain Georgios answers Metodiu with terms taken from Nietzsche's aesthetics: "it's a sight where you have to be all eyes. Beauty always hides danger, as the Dionysian stands crouched behind the Apollonian" (Groşan 2012: 344).

We can also find the elevated/sacred blended with the colloquial/profane; for example, a religious gesture presented with a phrase used when bargaining. "Iovănuț made two or three, let's say four signs of the cross, and walked away hastily" (Groşan 2012: 34); or the idyllic with the brutal, as in "A light breeze was blowing, and there was a lovely smell you felt it blew your head" (Groşan 2012: 8); play on words, for example, when Cadâna asked the sultan what he wanted: "massage or vernissage" (Groşan 2012: 58), or the "scientific" explanations provided as footnotes by the author (Groşan 2012: 21): "Where are the bees, the beet*, the Cotnari wine, where's my wine, in general? Ubi sunt?". The elevated motif of the passage of time taken from mediaeval literature is used for indicating the lack of the banished ruler's favourite foods. The footnote remarks the following: "In the text, there is an inconsistency with the truth. The beet was introduced in Moldavia after the 1848 Revolution" (Groşan 2012: 21).

\section{Conclusions}

This novel is an illustrative example of a certain genre and period, namely postmodern historical metafiction, where history is just a (pre)text for the author to provide the audience and himself - through humour - a way of escape and defiance. And the way he does it is marvellous because Groşan uses "capitalist" devices - in the sense that the postmodern techniques arrive from the West and, as we saw above, the West is also assimilated with capitalism - to escape communism, where, as the characters' whisper in the final sentence of the novel reveals, "it is not good [...] for us, either" (Groşan 2002: 359). As could be seen, the author uses humour both at the micro level - in order to escape by creating an alternative world - and 
at the macro level - producing cracks in the reality of the system, highlighting flows and follies of the system -, hoping that the audience will be able to recognize them. Although they cannot liberate themselves from the system, they can smile and mock at it, gaining a kind of evasion in the form of spiritual superiority.

The primary audience of the novel is the Romanian one, but we would like to reconnect with a more than 100-year-old thought of Witcombe: "there are a few great novels which do not show the influence of more than one nationality" and, consequently, "the history of fiction is largely a study of international relations" (qtd. in Amigoni 2000: 149). The internationalism of fiction is present in this novel, as we could see in the universe presented, by depicting a cross-, multi-, and international hybrid universe, in which Romanian culture mingles with the Hungarian, the Turk, and the Tatar one. Eclecticism also has blind spots, of course, by deleting borders and offering thus a general view. A global view sometimes stops one from the possibility of gaining a deeper knowledge of something or someone.

Finally, even if, due to its bookish, intertextual character, the target audience is quite narrow (the connoisseurs), humour saves the situation. Firstly, humour makes possible the publishing of the text in a totalitarian regime, giving it a greater chance to deceive censorship. Secondly, it is also able to engage the reader in a play mode, broadening thus the circle of readers (because the book can be enjoyed even without the identification of each reference).

\section{References}

Amigoni, D. 2000. The English novel and prose narrative. Edinburgh: Edinburgh University Press.

Bhabha, H. K. 1994. The location of culture. London: Routledge.

Caragiale, M. 2011. Gallants of the old court. Bucharest: Paideia.

Cărtărescu, M. 2010. Postmodernismul românesc [Romanian Postmodernism]. Bucharest: Humanitas.

Cliveț, N. 2001. Ioan Groşan. Monograph. Braşov: Aula.

Comisia Prezidențială pentru Analiza Dictaturii Comuniste din România [Presidential Commission for the Study of the Communist Dictatorship in Romania]. 2006. Raport Final [Final report]. Bucharest.

http://old.presidency.ro/static/rapoarte/Raport_final_CPADCR.pdf (downloaded on: 18 April 2020).

Cornis-Pope, M. 2004a. From resistance to reformulation. In: Marcel Cornis-PopeJohn Neubauer (eds.), History of the literary cultures of East-Central Europe: Junctures and disjunctures in the $19^{\text {th }}$ and $20^{\text {th }}$ centuries. Volume XIX (Volume I in the subseries on Literary Cultures). Amsterdam-Philadelphia: John Benjamins Publishing Company. 39-51. 
2004b. Shifting perspectives and voices in the Romanian novel. In: Marcel CornisPope-John Neubauer (eds.), History of the literary cultures of East-Central Europe: Junctures and disjunctures in the $19^{\text {th }}$ and $20^{\text {th }}$ centuries. Volume XIX (Volume I in the subseries on Literary Cultures). Amsterdam-Philadelphia: John Benjamins Publishing Company. 441-455.

2004c. The search for a modern, problematizing historical consciousness: Romanian historical fiction and family cycles. In: Marcel Cornis-Pope-John Neubauer (eds.), History of the literary cultures of East-Central Europe: Junctures and disjunctures in the $19^{\text {th }}$ and $20^{\text {th }}$ centuries. Volume XIX (Volume I in the subseries on Literary Cultures). Amsterdam-Philadelphia: John Benjamins Publishing Company. 499-505.

Dekoven, M. 2009. History, the twentieth century, and a contemporary novel. $A$ Forum on Fiction 42(2) (Summer): 332-336.

Djuvara, Neagu. 1995. Între Orient şi Occident. Țările române la începutul epocii moderne [Between East and West. The Romanian Principalities in the first half of the $19^{\text {th }}$ century]. Bucharest: Humanitas.

Farber, J. 2007. Toward a theoretical framework for the study of humor in literature and the other arts. The Journal of Aesthetic Education 41(4) (Winter): 67-86.

García Márquez, G. 2003. One hundred years of solitude. New York: Harper.

Groşan, I. 2009. The cinematography caravan. Plymouth: UPP.

2012. O sută de ani de zile la Porțile Orientului [One hundred years at the gates of the East]. Iaşi: Polirom.

Hassan, I. 1986. Pluralism in Postmodern Perspective. Critical Inquiry 12(3) (Spring): 503-520.

Hutcheon, L. 1988. A poetics of Postmodernism. London: Routledge.

Hyman, L. S. 2019. JFK. The Kennedys and me. New York: Page Publishing, Inc.

Jáuregui Narváez, E. 2014. El sentido del humor. Manual de instrucciones [The sense of humor. Manual of instructions]. Madrid: Espasa y Calpa.

Jauss, H. R. 2005. Toward an aesthetic of reception. Minneapolis: University of Minnesota Press.

Morreall, J. 1983. Taking laughter seriously. Albany: State University of New York Press.

2008. Philosophy and religion. In: Victor Raskin (ed.), The primer of humor. Berlin-New York: Research Mouton de Gruyter. 211-242.

Phelan, J.-Rabinowitz, P. J. et al. 2012. Reception and the reader. In: Herman, D. et al. (eds.), Narrative theory. Core concepts and critical debates. Columbus: Ohio State University Press. 139-159.

Popa, C. 2017. Levantini, orientali, balcanici (ipostaze ale Celuilalt în literatura postmodernistă românească a anilor '80-'90) [Levantines, Orientals, Balkans (hypostases of the Other in the Romanian postmodernist literature of the '80s 
and '90s]. In: Ajtony, Zs. et al. (eds.), Stranger/Străinul. Miercurea Ciuc: Status. 198-208.

Russo, Al. 1943. Scrieri postume [Posthumous writings]. Craiova: Scrisul Românesc. Sadoveanu, M. 2004 [1928]. Tales from Ancuța's Inn. Bucharest: Institutul Cultural Roman.

Spiridon M. 2004. Models of literary and cultural identity on the margins of (Post)modernity: The case of pre-1989 Romania. In: Marcel Cornis-Pope-John Neubauer (eds.), History of the literary cultures of East-Central Europe: Junctures and disjunctures in the $19^{\text {th }}$ and $20^{\text {th }}$ centuries. Volume XIX (Volume I in the subseries on Literary Cultures). Amsterdam-Philadelphia: John Benjamins Publishing Company. 65-69.

Stamm, J. R. 1959. The use and types of humor in the picaresque novel. Hispania 42(4): 482-487.

Stan, A. 2008. Stand-up history. Tribuna 132: 5.

Sicher, E.-Weinhouse, L. 2012. The Postmodern Jew. In: Under postcolonial eyes: Figuring the "Jew" in contemporary British writing. Lincoln-London: University of Nebraska Press. 176-198.

Stephenson R. M. 1951. Conflict and control functions of humor. American Journal of Sociology 56(6): 569-574.

Țifrea, O. 2008. Recunoaşterea umorului în texte [The recognition of humour in texts]. https://profs.info.uaic.ro/ corinfor/Humor-Oana.pdf (downloaded on: 18 April 2020).

Verdery, Katherine. 1991. National ideology under socialism. Identity and cultural politics in Ceauşescu's Romania. Berkeley-Los Angeles-Oxford: University of California Press. 